\title{
EFFECTS OF INFLUENT COMPOSITION ON BIOLOGICAL ACTIVITY, ACCLIMATION TIME AND MICROBIAL COMMUNITY PROFILE OF ACTIVATED SLUDGE
}

\section{Viviane Nascimento ds Silva e Sá ${ }^{1}$, Jessica Rodrigues Pires da Silva ${ }^{2}$, Clarissa da Silva Moura ${ }^{1}$, Carla CarolineMachado de Oliveira ${ }^{1}$, Leila Yone Reznik ${ }^{1}$, Cristiano Piacsek Borges ${ }^{2}$, Tito Lívio Moitinho Alves $^{2}$ and Fabiana Valéria da Fonseca ${ }^{1}$}

${ }^{1}$ School of Chemistry, Federal University of Rio de Janeiro, Av Athos da Silveira Ramos, 149 - University City, Rio de Janeiro - RJ, 21941-909, Brazil; ${ }^{2}$ COPPE/Chemical Engineering Program, Federal University of Rio de Janeiro, Av Horácio Macedo, 2030 - 101 - University City, Rio de Janeiro - RJ, Brazil

\section{ARTICLE INFO}

\section{Article History:}

Received $17^{\text {th }}$ October, 2020

Received in revised form

$21^{\text {st }}$ November, 2020

Accepted $11^{\text {th }}$ December, 2020

Published online $30^{\text {th }}$ January, 2021

\section{Key Words:}

Acclimation process; Activated sludge; MALDI TOF-MS; Startup; Wastewater treatment.

\begin{abstract}
Background: The performance and stability of activated sludge (AS) processes are strongly related to influent wastewater characteristics. Objective: To investigate the influence of different chemical compositions of influent wastewater, in terms of source of carbon, on activated sludge. Methods: Response was measured in oxygen uptake rate (OUR), volatile suspended solids in the mixed liquor (MVLSS), chemical oxygen demand (COD), and microbial community profile, obtained using Matrix-Assisted Laser Desorption Ionization-Time-of-Flight Mass Spectrometry (MALDI-TOF MS). Results: Results showed that the microbial community profile obtained in both reactors is consistent with those reported for full-scale AS bioreactors treating sewage. However, when the source of carbon is less bioavailable (bioreactor 1), there was a statistically significant difference (pvalue $<0.05,95 \%$ confidence) in the biological activity of the biomass, both in terms of MLVSS growth and OUR in comparison with the reactor with source of carbon more bioavailable (bioreactor 2). This difference also impacted the time required for complete acclimation: it could be considered completed in 15 days in bioreactor 2, whereas in bioreactor 1 , acclimation required more than 120 days to be completed, as during this period there was no net biomass growth even though there was high COD removal.
\end{abstract}

*Corresponding author:

Viviane Nascimento ds Silva e Sá,

Copyright (C) 2021, Viviane Nascimento ds Silva e Sá et al. This is an open access article distributed under the Creative Commons Attribution License, which permits unrestricted use, distribution, and reproduction in any medium, provided the original work is properly cited.

Citation: Viviane Nascimento ds Silva e Sá, Jessica Rodrigues Pires da Silva, Clarissa da Silva Moura, Carla CarolineMachado de Oliveira et al., 2021. "Effects of influent composition on biological activity, acclimation time and microbial community profile of activated sludge", International Journal of Development Research, 11, (01), 44028-44034.

\section{INTRODUCTION}

Activated sludge (AS) plays a crucial role in domestic and industrial wastewater treatment, as it is bothan efficient and relatively economic alternative for biological wastewater treatment. It is recognized that the development of bacterial communities and consequently the overall performance ofAS depends on the bacteria and on the chemical composition of the incoming wastewater (IW)and as a result, studies have been investigating the response of AS process to IW with different biochemical compositions. Some examples include IW containing pharmaceuticals (SILVA et al., 2020) nanoparticles (NPs) (QUAN et al., 2015; ZHOU; XU, 2019), high loads of organic matters (WEI; JIN; ZHANG, 2020) and nutrients (LI et al., 2020). Synthetic solutions are used as IW for such studies to ensure the reproducibility of the IW throughout the entire period of evaluation. It is generally accepted that synthetic solutions are representative of real wastewaters provided an acclimation is done, though the acclimation procedure is not standardized as its progression depends on the characteristics of the synthetic solution and the biomass response. Despite the widespread use of synthetic solutions in the literature, studies investigating the relationship between the chemical composition of synthetic solution and the evolution of acclimation, including its effects on biomass and on the process, are less common (CAI; JU; Zhang, 2014; Liwarska-Bizukojc; Galamon; Bernat, 2018). Furthermore, considering that IW act as the substrate for the formation of microbial communities(ZHOU; XU, 2019), and since real wastewaters have a chemical composition much more complex than a synthetic solution, there may exist significant differences in the microbial community profile of sludges subjected to synthetic solutions (CAI; JU; Zhang, 2014; LIWARSKA-BIZUKOJC; GALAMON; BERNAT, 2018; LI et al., 2020). The molecular biology technique of 16S rRNA gene sequencing is frequently used for microbial community identification in sludges with a high level of certainty, but since it is still an expensive, technical-demanding, and time-consuming method, alternative methods are desirable, particularly for wastewater treatment applications (CARBONNELLE 
et al., 2015; GUO et al., 2015; ANTUNES; BALLARINI; SAND, 2019). Thus, in the present work, Matrix-Assisted Laser Desorption Ionization-Time-of-Flight Mass Spectrometry (MALDI-TOF MS) method was used instead for the identification of microbial community profile, which represents a suitable alternative, mainly because it is a fast and relatively simpler method (Rahi; Prakash; Shouche, 2016). This method provides a mass spectral fingerprint of the microorganisms that is unique for each microorganism and is compared to the database for identification (Kirchman, 2002). MALDI-TOF MS isa fast-growing method in microbial ecology and there are some recent studies using this method in environmental samplesin the context of wastewater treatment, nonetheless its use remains limited in literature for applications in activated sludge for wastewater treatment (Kirchman, 2002). In order to adress the issues mentioned above, the purpose of this study was to evaluate the influence of different chemical compositions of IW, namely in terms of sources of carbon, on biological activity, acclimation time and microbial profile of AS biomass obtained by MALDI-TOF MS. Through the results obtained, the following questions were addressed: i) is there a statistically relevant difference ( $p$-value less than the confidence interval) between the biological activity of the two reactors when the operational difference is only the source of carbon? ii) If so, how does this result affect the time needed to reach complete biomass acclimation? and iii) are the tested synthetic feeds capable of being a substrate for forming a microbial profile similar to that found in full-scale AS reactors treating real IW?

\section{MATERIALS AND METHODS}

Chemicals and materials: Synthetic IW was prepared with analytical reagents from Kasvi ${ }^{\circledR}$ and Plate Count Agar (PCA) was used as a solid medium for microbial cultivation. All reagents were of analytical grade and used without further purification.Two synthetic feeds differing only in the sources of carbon and nitrogen were selected as incoming wastewater (IW) and each was fed in a different reactor (Bioreactor 1 and 2). Table 1 summarizes the compositions of each synthetic IW; these compositions were adapted fromHoller and Trösch(2001). The different sources of carbon studied were meat peptone and glucose, and the different sources of nitrogen studied were urea and ammonium chloride, representing in bioreactor 1 (B1) an IW more difficult to biodegrade and with less bioavailable nitrogen and in bioreactor 2 (B2) a more easily degradable IW and with readily available nitrogen.

Experimental Set-up : B1 and B2 were operated in continuous mode for 120 days, each receiving different IW (Table 1) and operating under identical conditions: neutral $\mathrm{pH}$, temperature $28 \pm 2{ }^{\circ} \mathrm{C}$, dissolved oxygen (DO) above $4.0 \mathrm{mg}$. $\mathrm{L}^{-1}$, Hydraulic Retention Time (HRT) of $48 \mathrm{~h}$ and complete sludge retention.Both bioreactors were operated in parallel under identical hydrodynamic conditions.Mixed liquor (ML) collected from AS tank from a local domestic wastewater treatment plant was used as inoculum at the startup of the bioreactors. ML was mixed with synthetic wastewater freshly prepared for B1 and B2. In each case, a sludge: wastewater 1: 3 ratio was used giving a Mixed Liquor Volatile Suspended Solids (MLVSS) of $5 \mathrm{~g}$. $\mathrm{L}^{-1}$. At the startup, each reactor received the respective IW (Table 1). However, over operating time due to the experimental results obtained in B1, concentration of IW that fed B1 was increased, first by $50 \%$ and then by $100 \%$ in weight, as further discussed in Results section. Experimental setup is illustrated in Error! Reference source not found..

\section{ANALYTICAL METHODS}

Physical-chemical sample characterization: Chemical Oxygen Demand (COD), pH, Oxygen Uptake Rate (OUR), Specific Oxygen Uptake Rate (SOUR), nitrate and Mixed Liquor Volatile Suspended Solids (MLVSS) were determined according to the "Standard Methods for the Examination of Water and Wastewater"
(APHA/AWWA/WEF, 2012). Removal efficiency of each parameter by the bioreactor is calculated according to Equation1.

Removal $(\%)=(C f-C o) / C f x 100$

Where $\mathrm{C}_{\mathrm{f}}$ is the concentration of the parameter in the biologically treated effluent and $\mathrm{C}_{0}$, in the influent

Microscopic analysis: Sludge characteristics were observed using an optical microscope with an optical enlargement of 400x. A $5 \mathrm{~mL}$ sample of mixed liquor was taken from the reactors. After sludge settling, samples were placed on microscopy slides and covered by cover slips without dipping oil or dyes. Higher organisms were identified through physical characteristics (shape, presence of cilia and mobility).

MALDI-TOF MS analysis of microorganism in sludge: Identification of microbial species in sludge were made in a MALDTI-TOF MS equipment model Biotyper Systems (Bruker ${ }^{\circledR}$ ) using Software MALDI Biotyper (Version 3.0-Bruker ${ }^{\circledR}$ Daltonik, Germany). Analyses were performed in the mixed liquor of B1 and $\mathrm{B} 2$ at the end of the bioreactors' continuous operation period. A total of 251 of microbial isolates were selected based on their distinctive morphological characteristics (shape, size, elevation, surface, edges, color and structure). This procedure has been described inSilva et al. (2020).

\section{Statistical analysis}

Hypothesis tests were performed in "Microsoft Excel v.2019"software to assess the hypothesis that the biological activity of $\mathrm{B} 1$ and $\mathrm{B} 2$ was the same (null hypothesis, $\mathrm{H}_{\mathrm{o}}$ ). Considering that in this work, the biological activity was measured in terms both of MLVSS and OUR, for the statistical analysis, the following population pairs were considered: pair 1, MLVSS of B1 and B2 over the time of operation;pair 2, OUR of B1 and B2 over the time of operation. Separate tests were performed for each pair of populations. The test performed was the student's t-test with a $95 \%$ confidence interval.

\section{RESULTS AND DISCUSSION}

Biological activity: Both bioreactors (B1 and B2) were operated in parallel under four different DQO ratio. Reactor B1 operated with three chemical oxygen demand (COD) load variations, and in reactor B2 the feed was fixed. Within the range investigated in the present study, the decrease in sludge concentration due to endogenous respiration and biomass lysis during aerobic stabilization depended on the feed composition. Figure 2 shows the biological activity results for MLSS, OUR, and SOUR in reactors B1 and B2. The biological activity of biomass was measured by the oxygen consumption, given by the respirometry and calculation of the oxygen uptake rate, and by microbial growth, given by the evolution of the suspended solids in the reactor (MLVSS). As the operation progressed, a trend of decreasing solids in B1 became clear (Figure 3), which was not observed in B2, where solids were constant. This downward trend is not shown clearly in Figure 2 (B1-original feed) because the decrease occurred gradually and in the first few weeks MLVSS was still high, due to the startup at a high value (5 g.. $\mathrm{L}^{-1}$ of MLVSS), used to absorb the expected initial fluctuations in the microorganism adaptation process. However, even with prolonged aeration and total sludge recirculation, which should maintain a higher MLVSS, in the range of 3.0 to 5.0 g.L-1 (LIN, 2007), the concentration of solids in B1 did not increase. This may indicate that the heterotrophic bacteria were not yet adapted to the composition of synthetic influent in the case of B1. (MOZUMDER et al., 2014) discussed the time needed to acclimatize reactors and reported the strong influence that the starting conditions have on the following stages. In B2, MLVSS remained stable, showing net sludge production, expected in acclimatized and stabilized sludge. The downward trend in MLVSS in B1 remained after 30 days of operation, therefore an acclimation strategy was adopted by increasing feed concentrations. 


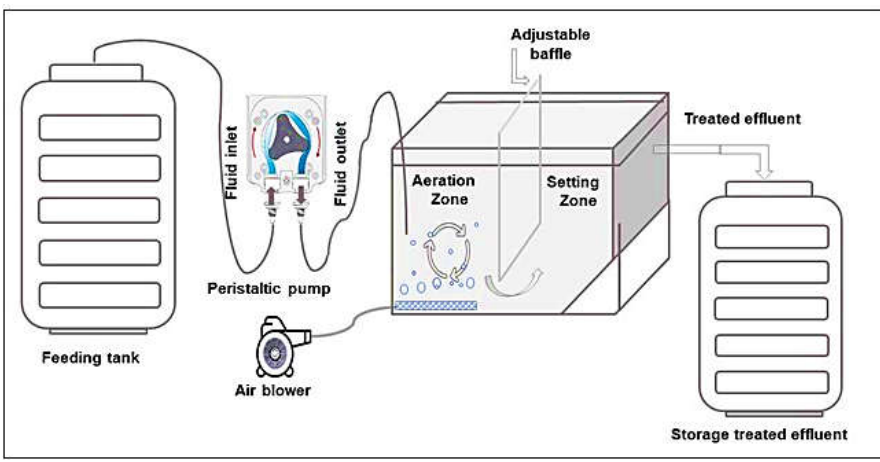

Figure 1. Experimental setup for both bioreactors

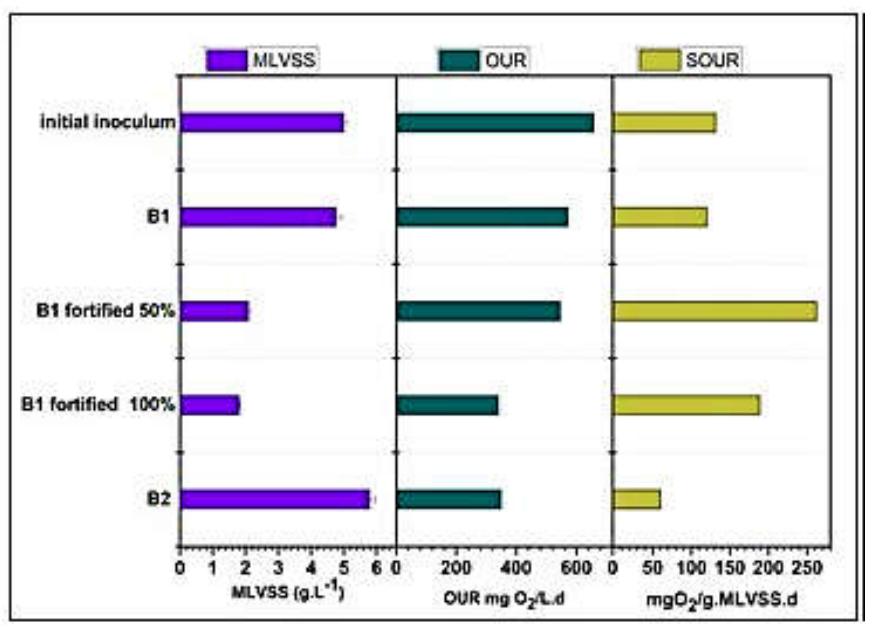

Figure 2. Average values and standard deviation of MLVSS, OUR and SOUR over the operation time for each feeding condition
B2. The lower OUR results obtained in the reactors in relation to the inoculum, which are particularly noticeable in B2, may be due to the fact that in binary substrate systems such these bioreactors (meat extract in B1 and glucose in B2, in both cases mixed with yeast extract), the rate of biodegradation remains slow, generally owing to competitive inhibition biodegradation (SINGH; BALOMAJUMDER, 2016). Over the operation time, there was a relative stability in the OUR values in B2 and in B1 (Figure 2). This stability is illustrated by the low dispersion of all data around the average value: the coefficient of variation was $21.3 \%$ in B1 with $100 \%$ fortified feed and $18.6 \%$ in B2. In the case of impaired biological activity, a continuous reduction in the OUR over time rather than stability would be expected, especially in the case of B2, since there was constant amount of aerobic biomass in the mixed liquor. Therefore, in this case, lower OUR valueswere not attributed to impaired biological activity in the bioreactors, but rather to lower rates of biodegradation resulting from the synthetic IW used. Statistical analyzes with Student's t-test were performed usingthe MLVSS and OUR values measured in the two reactors. It showed that there is statistically relevant difference (pvalue $<0.05,95 \%$ confidence) for both the OUR ( $p$-value 0.000759 ) and MLVSS (p-value 0.00081) when comparing B1 to B2. Therefore, overall biological activity of biomass subjected to IW made of meat peptone and urea (B1) was different compared to biomass subjected to IW made of D-glucose and ammonium nitrogen (B2), considering the same inoculum. This may be due to the very easy biodegradation of D-glucose and easy assimilation of ammonium chloride fed to B1 compared to the meat extract and urea fed to B2.

Acclimation time: The procedure for acclimatizing bioreactors is not standardized, as it depends on the characteristics of each process e.g. IW, biomass and operating conditions. Thus, in order to check the acclimation of AS biomass, authors may use the removal of organic matter and other process parameters(SILVA et al., 2020), respirometry(FERRO OROZCO et al., 2013), among others. Considering these references, it was defined that to assess the progress

Table 1. Composition of synthetic wastewater for B1 and B2

\begin{tabular}{llll}
\hline Bioreactor 1 (B1) & & Bioreactor 2 (B2) & Concentration $\left(\mathrm{g}\right.$. L $\left.{ }^{-1}\right)$ \\
\hline Reagents & Concentration $\left(\mathrm{g}\right.$. $\left.\mathrm{L}^{-1}\right)$ & Reagents & 0.61 \\
meat peptone & 0.16 & D-glucose & 0.47 \\
yeast extract & 0.11 & yeast extract & 0.06 \\
urea & 0.05 & ammonium chloride & 0.04 \\
monosodium dihydrogen orthophosphate & 0.028 & monosodium dihydrogen orthophosphate & 0.015 \\
sodium chloride & 0.007 & sodium chloride & 0.015 \\
calcium chloride & 0.004 & calcium chloride & 0.015 \\
magnesium sulfate & 0.035 & magnesium sulfate & 0.20 \\
sodium bicarbonate* & 0.1 & sodium bicarbonate* & \\
\hline
\end{tabular}

Table 2. Occurrence of microorganisms in microscopic slides during operation

\begin{tabular}{llllll}
\hline Microorganisms & Inoculum & B1 & B1 (fortified 50\%) & B1(Fortified 100\% ) & B2 \\
\hline Helminth eggs and larvae & ++ & + & + & - & - \\
Filamentous bacteria & + & + & + & - & - \\
Crawling protozoa & - & + & + & ++ & ++ \\
Ameboid protozoa & - & ++ & ++ & ++ & ++ \\
Freely floating protozoa & - & + & + & - & - \\
Algae & + & + & - & +++ & - \\
Fungi & - & - & + & +++ & ++ \\
Metazoa (rotifers) & & + & + & ++ \\
* increase in relation to Table 1; - no individual per field, ++ few individuals per field, +++ or ++++ many individuals per field
\end{tabular}

Originally the increase was $50 \%$ in relation to concentrations in Table 1 , and after another 45 days of operation, there was a further increase, this time of $100 \%$ in relation to the original. However, the downward trend of the MLVSS remained, indicating that withdrawals three times a week to monitor MLVSS and microscopy still exceeded the sludge's net production capacity. When introducing load 100\% more concentrated in related to original, the MLVSS had a sudden drop to values around $1.5 \mathrm{~g}$. $\mathrm{L}^{-1}$, indicating that the system was unstable. The drop in OUR in this case was probably due to less biomass present in the medium performing aerobic respiration. Even considering the OUR decrease in B1, the final values were still close to those found in of reactor acclimation in this study, in addition to the biological activity of biomass, previously discussed, the removal of organic matter in the reactor was also considered in terms of COD removal and sludge characteristics, particularly regarding organisms as protozoa, nematodes, rotifers and filamentous bacteria. Error! Reference source not found. shows the average organic matter in influent and effluent. The removal efficiency of organic matter between $90-95 \%$ is expected for aerobic systems operating at prolonged aeration for biodegradable wastewater (METCALF \& EDDY (AECOM), 2016). Thereby, in terms of removing organic matter, there was no significant difference ( $p$-value $>0.05,95 \%$ 
confidence) between B1 and B2. 30and 7 days were necessary for the removal of organic matter to reach $90 \%$ in the $\mathrm{B} 1$ and $\mathrm{B} 2$, respectively. Even with the decrease in biomass in the B1 over time (Figure 3), the remaining biomass maintained its removal capacity of organic matter. The appropriate operational condition of AS is characterized by high a content of ciliates, both settled and freely floating, by the occurrence of rotifers and nematodes, by a low population number of flagellates, and by lack of fungi and filamentous bacteria. In contrast, poor condition of AS presents low content of ciliates and a high frequency of filamentous bacteria, flagellates, and fungi (SOWINSKA et al., 2017). Table 2presents the detection of microorganisms in the optical microscopy analysis throughout operation time ( + for the presence and - for absence). Sludge in the inoculum showed the characteristics of appropriate operational condition, but the monitoring of the microbial profile in mixed liquor indicated that the microbial community reacted immediately to introducing the IW and then gradually changed, in an ecological succession process. In the first weeks of operation in B1 abundance and variety of ciliated protozoa decreased, pointing to a worsening of the sludge quality.

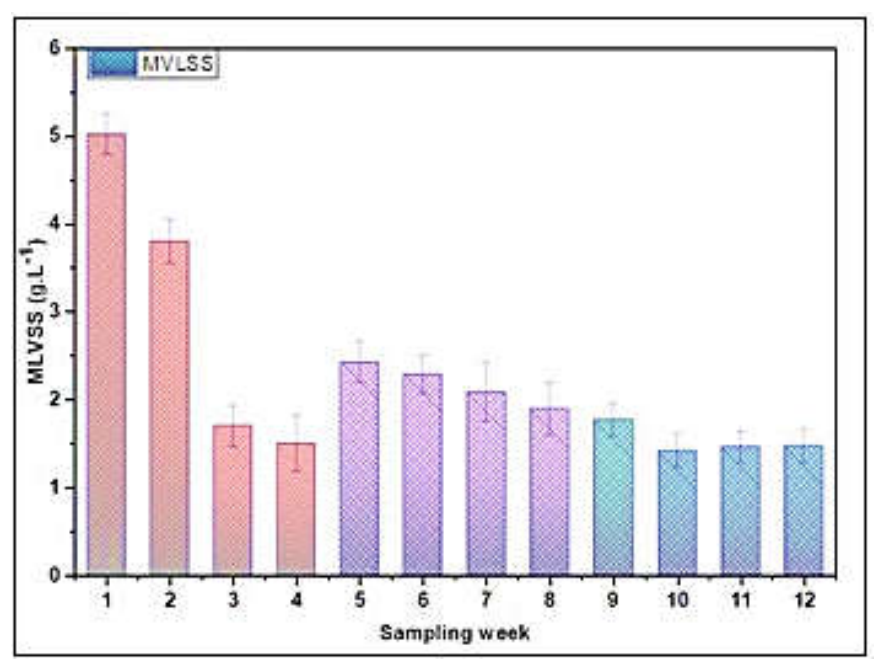

Figure 3. MLVSS in Bioreactor 1 over operating time

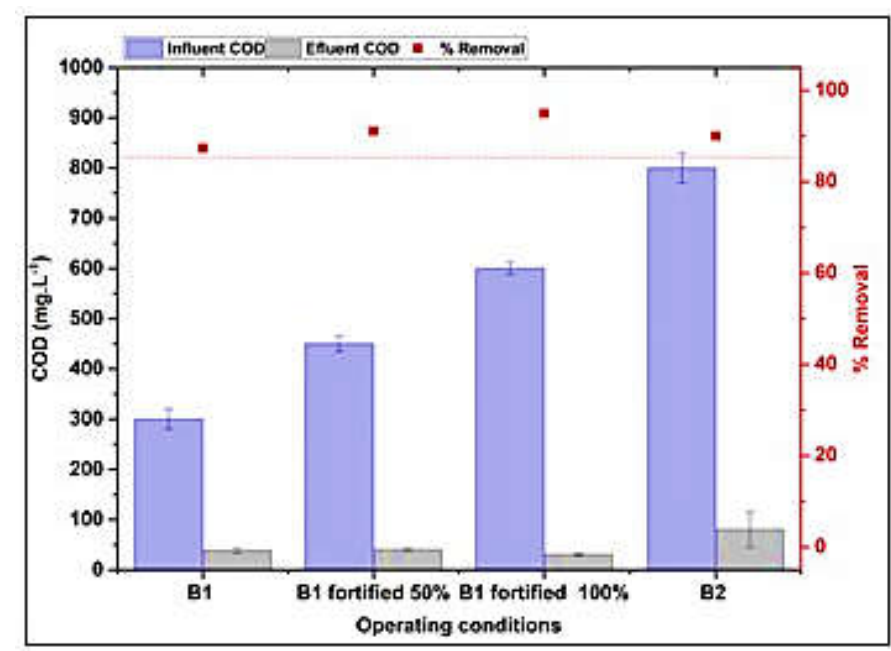

Figure 4. Average COD values of wastewater influent and effluent, as well as COD removal percentage. The values represent the mean \pm standard deviation (SD). Red line represents that \% removal was greater than $85 \%$ in all operating conditions

The presence of filamentous bacteria in B1, although in low concentration, may have favored the floating of biomass, reflected in the higher turbidity found in the effluent treated in this condition compared to B2. Algae were only present in the initial period, indicating that they were more sensitive to variations in the influent's composition and the appearance of other microorganisms. The increase in organic load in B1 and longer operation time (higher than
15 days) in both reactors favored an increased in protozoa abundance and biodiversity in B1 and B2, mostly free ciliates. This is an indicator of good quality and stability of the system.

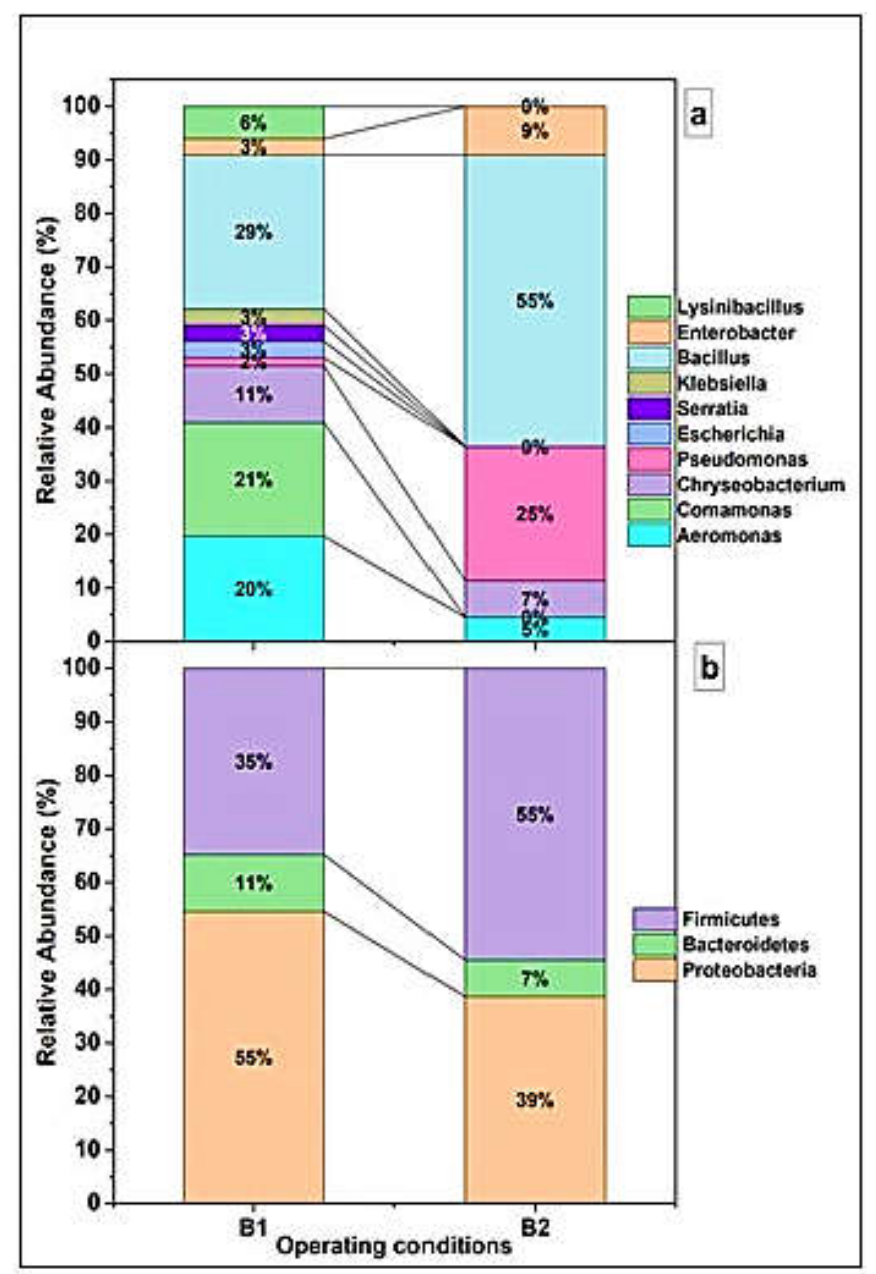

Figure 5-Microorganisms identified by MALDI-TOF MS. Classification by phylum (A) and genus (B). Percentages calculated over the total number of samples that obtained a score higher than 1.7.

The increase in these organisms can be explained by the increase in the bacterial population, which also increases free ciliates that feed on them. In the case of B2, this increase in the bacterial population was more significant as indicated by the production of solids yielding constant MLVSS values over time, which may be the reason for a greater number of crawling, ameboid and freely floating protozoa identified in B2 mixed liquor. Since these organisms remove nonflocculent bacteria and very small sludge flocs that would not settle, improving sludge sedimentation, they may have contributed to the lower turbidity of the B2 effluent compared to the B1 effluent. Considering all acclimation parameters, B2 acclimation could be considered completed after 15 days, as after this period biomass growth in MLVSS, OUR stability, removal of organic matter above $90 \%$ and adequate sludge microscopy were observed. In the case of RA, this time is greater than 120 days, because in this period there was no net biomass growth, even though the other parameters were already within the expected and comparable with the RB after 30 days. Research on biological treatment using AS under adverse operation conditions reported satisfactory biological degradation in terms of organic matter removal, but with decrease of MLVSS over time, when considering periods of operation similar to the present study(WANG; JI; WANG, 2014; LUO et al., 2015; RAZA et al., 2020). This indicates that considering only parameters such as organic matter removal is insufficient to inform the stage of biomassacclimation, since organics removal can reach satisfactory levels before the biomass growth is stabilized. This observation is corroborated by the results of the present work. Furthermore, the present results show that the source of carbon influenced the time necessary for complete biomass acclimation, increasing significantly 
the time when there is less bioavailability of carbon, which was expected considering that it had previously been demonstrated that the source of carbon influenced the biological activity of biomass.

Microbial profileby MALDI-TOF MSfor selected bacteria: Overall, a total of 251 microbial isolates were analyzed by MALDI-TOF MS,of which 3 phyla and 10 genera were identified. Abundance relative for phylum and genus are categorized inFigure 5.Only microorganisms identified with a score higher than 1.7 (i.e. probable identification for genus) are presented. Phylum Proteobacteria was dominant in B1 (55\%) and phylum Firmicuteswas dominant in B2 (55\%). Microorganisms from the phylum Proteobacteria use several sources of carbon and remove nitrogen from wastewater (PENG et al., 2018). Those from the phylum Firmicutes are versatile in the degradation of various environmental substrates (GAO et al., 2016). Phylum Bacteroidetes was also identified; it is important in the formation of biofilm and degradation of biopolymers (KIRCHMAN, 2002). Taxonomic analysis at the genus level can provide more information about such relationships(ZHANG; SHAO; YE, 2012; GAO et al., 2016). Pseudomonas, Chryseobacterium, Bacillus and Enterobacter were commonly present in the two reactors, but others were identified in at least one of those conditions. Genus Pseudomonas is associated with the denitrification process (ABD-ELHALEEM et al., 2007; ZHANG et al., 2014). Genus Chryseobacterium is associated with floc formation, removal of carbonaceous organic matter and nitrification-denitrification (LIU et al., 2010; KUNDU et al., 2014). Genus Bacillus was the most commonly found in all operating conditions. It is considered a typical member of microflora in activated sludges for municipal wastewater treatment (MIZUKI et al., 2001), and its presence in large quantities in the AS is considered an indication of the good quality of the sludge (SOWINSKA et al., 2017). This genus encompasses a great diversity of members that belong to the Bacillus group, which are all closely related and whose spectra are very similar. For this reason, differentiation at the level of species within this genus is very challenging not only in MALDI-TOF MS but also with the 16S rRNA gene sequencing method (RAHI; PRAKASH; SHOUCHE, 2016). This is also truth for species Enterobacter asburiae, Enterobacter cloacae, Enterobacter kobei, Enterobacter ludwigii and Enterobacter hormaechei, identified within the genus Enterobacter. They all belong to the complex Enterobacter cloacae (Ecc) and, therefore, they are difficult to distinguish at a species level using MALDI TOF MS (MEZZATESTA; GONA; STEFANI, 2012). Clinical and genomic studies have revealed an impressive facility of Ecc to acquire genes that encode broad-spectrum antibiotic resistance, making them some of the most worrisome microorganisms of the current antibiotic era (MEZZATESTA; GONA; STEFANI, 2012; UHLEMANN, 2019). Consequently, this genus deserves special attention in the context of environmental microbiology applied the study of the spread of microbial resistance genes in the environment.

Although the microbial population is influenced by the modification of the composition of the feed and the control parameters (ŚWIĄTCZAK; CYDZIK-KWIATKOWSKA, 2018; GUO et al., 2020), there is still a certain predominance of a core of genera bacterial such as Aeromonas, Pseudomonas, Enterobacter and Escherichia) in activated sludges that were also was also found in the present study, corroborating that the microbial profile found in B1 and B2 is within the typically described for full-scale AS reactors in literature(VÁZQUEZ-RODRÍGUEZ et al., 2011; ZHANG et al., 2015, 2019; PENG et al., 2018; OLUSEYI OSUNMAKINDE et al., 2019; XIE et al., 2019; XUE et al., 2019). It is noted that correct results for MALDI-TOF MS totalled 152 microbial or $61 \%$ of the total number of isolates. These values are close to those recently reported recently by Antunes et al. (2019), who applied MALDI-TOF MS to activated sludge samples from petrochemical wastewater and successfully identified between 50 and $65 \%$ of the isolated species. The number of specimens that did not generate spectra can be explained because they are of environmental origin, and MALDI-TOF database for such specimens is still limited (GAO et al., 2016). Overall, proteomic analysis are growing exponentially for several applications and therefore this inconvenience of the method should be overcome soon, even though developing a universal database is virtually impossible(KOPCAKOVA et al., 2014; ANTUNES; BALLARINI; SAND, 2019).

\section{CONCLUSIONS}

The comparison between the two bioreactors showed that when the source of carbon and nitrogen is less bioavailable (bioreactor B1), there was a statistically significant difference in the biological activity of the biomass, both in terms of MLVSS growth (p-value 0.00081) and of OUR (p-value 0.000759) in comparison with the reactor with carbon and nitrogen more bioavailable (bioreactor B2). This difference in biological activity impacted the acclimation time. In B2, acclimation could be considered completed in 15 days, since during this period biomass growth, OUR stability, removal of organic matter above $90 \%$ and adequate sludge microscopy were observed, whereas in $\mathrm{B} 1$, acclimation time was longer than 120 days, as in this period there was no net biomass growth although the other parameters had reached acceptable values. These led to a conclusion that considering only organic matter removal to indicate the state of acclimation of biomass, as is common in the literature, isinsufficient to inform the real stage of biomass acclimatization, as organic matter removal can reach high values before MLVSS growth stabilizes. In terms of microbial community profile, both reactors obtained profiles consistent with those reported for AS bioreactors fed with sewage, indicating that the use of the synthetic solution does not impair the formation of the expected microbial profile in the activated sludge. The methodology used in this work to evaluate the influence of the chemical composition of IW on the activated sludge biomass can be adapted to evaluate the influence of other types of IW on biomass of any aerobic biological process.

Acknowledgment: This work was supported by the Federal University of Rio de Janeiro and financed in part by the Coordenação de Aperfeiçoamento de Pessoal de Nível Superior - Brasil (CAPES) Finance Code 001 in the form of a scholarship to the co-author Jessica Rodrigues Pires da Silva.

\section{REFERENCES}

ABD-EL-HALEEM, D. et al. Detection of nitrate/nitrite bioavailability in wastewater using a luxCDABE-based Klebsiella oxytoca bioluminescent bioreporter. Journal of Microbiology and Biotechnology, v. 17, n. 8, p. 1254-1261, 2007.

ANTUNES, T. C.; BALLARINI, A. E.; SAND, S. V. D. Temporal variation of bacterial population and response to physical and chemical parameters along a petrochemical industry wastewater treatment plant. Anais da Academia Brasileira de Ciências, v. 91, n. 2, p. 1-16, 2019. Disponível em: $<$ http://www.scielo.br/scielo.php?script=sci_arttext\&pid=S000137652019000300616\&tlng=en>.

APHA/AWWA/WEF. Standard Methods for the Examination of Water and Wastewater. Standard Methods, p. 541, 2012.

CAI, L.; JU, F.; ZHANG, T. Tracking human sewage microbiome in a municipal wastewater treatment plant. Applied Microbiology and Biotechnology, v. 98, n. 7, p. 3317-3326, 2014.

CARBONNELLE, E. et al. MALDI-TOF mass spectrometry: An emerging technology for microbial identification and diagnosis. Frontiers in Microbiology, v. 6, n. 1, p. 1-16, 2015. Disponível em: $<$ http://dx.doi.org/10.1016/j.clinbiochem.2010.06.017>.

FERRO OROZCO, A. M. et al. Biodegradation of bisphenol-A (BPA) in activated sludge batch reactors: Analysis of the acclimation process. International Biodeterioration and Biodegradation, v. 85, p. 392-399, 2013. Disponível em: $<\mathrm{http} / / /$ dx.doi.org/10.1016/j.ibiod.2013.09.005>.

GAO, P. et al. Correlating microbial community compositions with environmental factors in activated sludge from four full-scale municipal wastewater treatment plants in Shanghai, China. 
Applied Microbiology and Biotechnology, v. 100, n. 10, p. 4663-4673, 2016. Disponível em: <http://dx.doi.org/10.1007/ s00253-016-7307-0>.

GUO, F. et al. Detailed investigation of the microbial community in foaming activated sludge reveals novel foam formers. Scientific Reports, v. 5, p. 1-9, 2015.

GUO, Y. et al. Monitoring stratification of anode biofilms in bioelectrochemical laminar flow reactors using flow cytometry. Environmental Science and Ecotechnology, v. 4, p. 100062, 1 out. 2020.

HOLLER, S.; TRÖSCH, W. Treatment of urban wastewater in a membrane bioreactor at high organic loading rates. Journal of Biotechnology, v. 92, n. 2, p. 95-101, 28 dez. 2001. Disponível em: $\quad<\mathrm{https}: / /$ www.sciencedirect.com/science/article/pii/ S0168165601003510?via\%3Dihub>. Acesso em: 26 mar. 2019.

KIRCHMAN, D. L. The ecology of Cytophaga-Flavobacteria in aquatic environments. FEMS Microbiology Ecology, v. 39, n. 2, p. 91-100, fev. 2002. Disponível em: <http://doi.wiley.com/ 10.1016/S0168-6496(01)00206-9>.

KOPCAKOVA, A. et al. Need for database extension for reliable identification of bacteria from extreme environments using MALDI TOF mass spectrometry. Chemical Papers, v. 68, n. 11, 1 jan. 2014. Disponível em: <http://www.degruyter.com/ view/j/chempap.2014.68.issue-11/s11696-014-0612-0/s11696014-0612-0.xml>.

KUNDU, P. et al. Simultaneous heterotrophic nitrification and aerobic denitrification by Chryseobacterium sp. R31 isolated from abattoir wastewater. BioMed Research International, v. 2014, 2014.

LI, S. et al. Adaptation of nitrifying community in activated sludge to free ammonia inhibition and inactivation. Science of the Total Environment, v. 728, 1 ago. 2020.

LIN, S. D. Water and wastewater calculations manual. 2. ed. [s.1.] Mc Graw Hill, 2007.

LIU, W. et al. Production and characterization of an intracellular bioflocculant by Chryseobacterium daeguense W6 cultured in low nutrition medium. Bioresource Technology, v. 101, n. 3, p. 1044-1048, fev. 2010. Disponível em: <https://linkinghub. elsevier.com/retrieve/pii/S0960852409011729>.

LIWARSKA-BIZUKOJC, E.; GALAMON, M.; BERNAT, P. Kinetics of Biological Removal of the Selected Micropollutants and Their Effect on Activated Sludge Biomass. Water, Air, and Soil Pollution, v. 229, n. 11, 2018.

LUO, W. et al. Water extraction from mixed liquor of an aerobic bioreactor by forward osmosis: Membrane fouling and biomass characteristics assessment. Separation and Purification Technology, v. 145, p. 56-62, 2015. Disponível em: $<\mathrm{http} / / / \mathrm{dx}$.doi.org/10.1016/j.seppur.2015.02.044>.

METCALF \& EDDY (AECOM). Tratamento de Efluentes e Recuperação de Recursos. 5. ed. [s.1.] Mc Graw Hill, 2016.

MEZZATESTA, M. L.; GONA, F.; STEFANI, S. Enterobacter cloacae complex: clinical impact and emerging antibiotic resistance. FUTURE MICROBIOLOGY, v. 7, n. 7, 2012.

MIZUKI, E. et al. Bacillus thuringiensis: A common member of microflora in activated sludges of a sewage treatment plant. Current Microbiology, v. 42, n. 6, p. 422-425, 2001.

MOZUMDER, M. S. I. et al. Effect of heterotrophic growth on autotrophic nitrogen removal in a granular sludge reactor. Environmental Technology, v. 35, n. 8, p. 1027-1037, 18 abr. 2014. Disponível em: <http://www.tandfonline.com/doi/ abs/10.1080/09593330.2013.859711>.

OLUSEYI OSUNMAKINDE, C. et al. Profiling Bacterial Diversity and Potential Pathogens in Wastewater Treatment Plants Using High-Throughput Sequencing Analysis. Microorganisms, v. 7, n. 11, p. 506, 29 out. 2019. Disponível em: <https://www.mdpi. com/2076-2607/7/11/506>.

PENG, Y. et al. Characteristics of microbial community involved in early biofilms formation under the influence of wastewater treatment plant effluent. Journal of Environmental Sciences, v. 66, p. 113-124, abr. 2018. Disponível em: <https://linkinghub. elsevier.com/retrieve/pii/S1001074216304144>.
QUAN, X. et al. Response of aerobic granular sludge to the long-term presence to nanosilver in sequencing batch reactors: Reactor performance, sludge property, microbial activity and community. Science of the Total Environment, v. 506-507, p. 226-233, 15 fev. 2015. Disponível em: <https://www.sciencedirect.com/ science/article/pii/S0048969714015976>. Acesso em: 16 abr. 2019.

RAHI, P.; PRAKASH, O.; SHOUCHE, Y. S. Matrix-assisted laser desorption/ionization time-of-flight mass-spectrometry (MALDITOF MS) based microbial identifications: Challenges and scopes for microbial ecologistsFrontiers in Microbiology, 2016. Disponível em: <www.frontiersin.org>. Acesso em: 4 fev. 2019.

RAZA, A. et al. Performance evaluation of concrete developed using various types of wastewater: A step towards sustainability. Construction and Building Materials, v. 262, p. 120608, nov. 2020. Disponível em: <https://linkinghub.elsevier.com/retrieve/ pii/S0950061820326131>.

SILVA, J. et al. Study of effects of pharmaceuticals on the activated sludge process combining advanced oxidation using ultraviolet/hydrogen peroxide to increase their removal and mineralization of wastewater. Journal of Environmental Chemical Engineering, p. 104576, 8 out. 2020. Disponível em: $<$ https://linkinghub.elsevier.com/retrieve/pii/S221334372030925 8>. Acesso em: 15 jan. 2021.

SINGH, N.; BALOMAJUMDER, C. Batch growth kinetic studies for elimination of phenol and cyanide using mixed microbial culture. Journal of Water Process Engineering, v. 11, p. 130-137, 2016. Disponível em: <http://dx.doi.org/10.1016/j.jwpe.2016.04.006>.

SOWINSKA, A. et al. Comparison of the results from microscopic tests concerning the quality of activated sludge and effluent. Water (Switzerland), v. 9, n. 12, p. 1-14, 2017.

ŚWIĄTCZAK, P.; CYDZIK-KWIATKOWSKA, A. Performance and microbial characteristics of biomass in a full-scale aerobic granular sludge wastewater treatment plant. Environmental Science and Pollution Research, v. 25, n. 2, p. 1655-1669, 1 jan. 2018.

UHLEMANN, A.-C. Multidrug-resistant Enterobacter cloacae complex emerging as a global, diversifying threat. [s.l: s.n.]v. 10

VÁZQUEZ-RODRÍGUEZ, G. A. et al. Standardization of activated sludge for biodegradation tests. Analytical and Bioanalytical Chemistry, v. 401, n. 4, p. 1127-1137, 2011.

WANG, D.; JI, M.; WANG, C. The stimulating effects of the addition of glucose on denitrification and removal of recalcitrant organic compounds. Brazilian Journal of Chemical Engineering, v. 31, n. 1, p. 9-18, 2014. Disponível em: <www.abeq.org.br/bjche>. Acesso em: 29 out. 2020.

WEI, Y.; JIN, Y.; ZHANG, W. Treatment of High-Concentration Wastewater from an Oil and Gas Field via a Paired Sequencing Batch and Ceramic Membrane Reactor. International Journal of Environmental Research and Public Health, v. 17, n. 6, p. 1953, 17 mar. 2020. Disponível em: <https://www.mdpi.com/16604601/17/6/1953>. Acesso em: 29 out. 2020.

XIE, W. M. et al. Dynamic characteristics of soluble microbial products in a granular sludge reactor. Journal of Cleaner Production, v. 212, p. 576-581, 1 mar. 2019. Disponível em: $<$ https://www.sciencedirect.com/science/article/pii/S0959652618 337909 >. Acesso em: 9 abr. 2019.

XUE, J. et al. Assessing the spatial and temporal variability of bacterial communities in two Bardenpho wastewater treatment systems via Illumina MiSeq sequencing. Science of The Total Environment, v. 657, p. 1543-1552, mar. 2019. Disponível em: $<$ https://linkinghub.elsevier.com/retrieve/pii/S004896971834986 $6>$.

ZHANG, L. et al. Composition of bacterial communities in municipal wastewater treatment plant. Science of the Total Environment, v. 689, p. 1181-1191, nov. 2019. Disponível em: <https://linkin ghub.elsevier.com/retrieve/pii/S0048969719330050>. Acesso em: 7 ago. 2019.

ZHANG, P. et al. Microbial communities, extracellular proteomics and polysaccharides: A comparative investigation on biofilm and suspended sludge. Bioresource Technology, v. 190, p. 21-28, 1 ago. 2015. Disponível em: <https://www.sciencedirect.com/ 
science/article/pii/S0960852415005659>. Acesso em: 16 abr. 2019.

ZHANG, T.; SHAO, M.-F.; YE, L. 454 Pyrosequencing reveals bacterial diversity of activated sludge from 14 sewage treatment plants. The ISME Journal, v. 6, n. 6, p. 1137-1147, 15 jun. 2012. Disponível em: <http:/www.nature.com/articles/ismej2011188>.

ZHANG, W. et al. Effects of cathode potentials and nitrate concentrations on dissimilatory nitrate reductions by Pseudomonas alcaliphila in bioelectrochemical systems. Journal of Environmental Sciences, v. 26, n. 4, p. 885-891, abr. 2014. Disponível em: <https://linkinghub.elsevier.com/retrieve/pii/ S100107421360460X>
ZHOU, H.; XU, G. Effect of silver nanoparticles on an integrated fixed-film activated sludge-sequencing batch reactor: Performance and community structure. Journal of Environmental Sciences, v. 80, p. 229-239, jun. 2019. Disponível em: $<$ https://linkinghub.elsevier.com/retrieve/pii/S100107421832361 $1>$. 